\title{
Effects of stocking density, energy and protein content on performance of broiler chickens raised during late wet season
}

\author{
Ademulegun, T. I. ${ }^{1 *}$ and Adeyemo, G. 0. ${ }^{2}$ \\ ${ }^{1}$ Nutrition and Dietetics Department, Rufus Giwa Polytechnic,Owo, Ondo State, Nigeria. \\ ${ }^{2}$ Department of Animal Science, University of Ibadan, Ibadan, Nigeria. \\ *Corresponding author. Email: tadext4@gmail.com.
}

Copyright (C) 2016 Ademulegun and Adeyemo. This article remains permanently open access under the terms of the Creative Commons Attribution License 4.0, which permits unrestricted use, distribution, and reproduction in any medium, provided the original work is properly cited.

Received 29th February, 2016; Accepted 28th April, 2016

\begin{abstract}
A 56-day feeding trial to investigate the effects of stocking density, energy and protein content on performance of broiler chickens during late wet season was carried out. In a $3 \times 2 \times 3$ factorial arrangement using completely randomized design, six diets with three energy and two crude protein levels were formulated. Three stocking densities (birds $/ \mathrm{m}^{2}$ ) of 10,12 and 14 were used. A total of 576 one-week old Arbor Acre broilers chickens were assigned to the respective diets and stocking density, at 32 birds per treatment. Weight gain, feed intake, feed conversion ratio, survival rate, carcass yield, live weight/ $\mathrm{m}^{2}$ and feed cost / live weight were assessed. Data were analyzed, using descriptive statistics and ANOVA $\alpha_{0.05}$. Energy $\mathrm{x}$ crude protein $\mathrm{x}$ stocking density interaction affects the feed intake $(p<0.05)$ and the highest value was obtained using diet with low energy and crude protein levels. Treatment did not affect $(p>0.05)$ survival rate, however, stocking density at $12 \mathrm{birds} / \mathrm{m}^{2}$ resulted in the best values $(p<0.05)$ of weight gain $(2230.71 \mathrm{~g})$ and feed conversion ratio $(2.10)$ and the use of diets with lower crude protein and energy increased $(p<0.05)$ the weight gain $(2312.42 \mathrm{~g})$. The carcass yield was affected $(\mathrm{p}<0.05)$ by the interaction of energy $x$ crude protein $x$ stocking density, $(p<0.05)$ with the lowest value $(67.33 \%)$ found with birds raised on stocking density, 10 birds $/ \mathrm{m}^{2}$ and diets with low crude protein and recommended energy. The lowest feed cost/live weight $(p<0.05)$ was observed with stocking density at 12 birds $/ \mathrm{m}^{2}$. Broiler chickens may be economically raised at stocking density 12 birds $/ \mathrm{m}^{2}$ and on diet containing $2933 \mathrm{kcal} / \mathrm{kg} \mathrm{ME}$ with $21.92 \%$ crude protein for starter phase and $3095 \mathrm{kcal} / \mathrm{kgME}$ and $19.14 \%$ crude protein for finishers during late wet season in Nigeria.
\end{abstract}

Key Words: Carcass yield, feed cost, feed conversion ratio, weight gain.

\section{INTRODUCTION}

Broilers, like any other living organism, must be provided with optimal environmental conditions and feed in order to achieve their genetic potential for growth (Feddes et al., 2002). The significance of stocking density (SD) in broiler production has long been established (Škrbić et al., 2009). However, the intensive selection work and creation of more productive genotypes has made the modern commercial lines of broiler chickens more demanding in terms of housing conditions, nutrition and handling (Škrbić et al., 2009). The ultimate goal of poultry producers is to maximize kilogram of chicken produced per square meter of space while preventing production losses due to overcrowding to achieve a satisfactory economic return (Abudabos et al., 2013). Although in higher SD, the profit per chicken decreases, total production of meat per unit of floor surface increases, and this results in higher profit (Ravindran et al., 2006). Stocking density as high as 20 birds $/ \mathrm{m}^{2}$ or $30-35 \mathrm{~kg} / \mathrm{m}^{2}$ had been suggested and used in environmentally controlled house (Thomas et al., 2004; Škrbić et al., 
2009), while SD varying from $6-14 \mathrm{bird} / \mathrm{m}^{2}$ had been used in open-sided houses (Yadgari et al., 2006, Yakubu et al., 2010). Several studies have been conducted to study the effect of SD on broilers production and performance. However, majority of these studies were inconclusive since some showed large benefits in reducing SD on the performance of broilers (Dozier et al., 2005, 2006; Škrbić et al., 2009), while others documented that reducing SD has no influence (Thomas et al., 2004) or even negative impacts on broilers' performance (Feddes et al., 2002, ElDeek and Al-Harthi, 2004). Apart from the physical stress that could be inflicted on the birds under high SD (Thaxton et al., 2006; Estevez, 2007), the metabolism of the nutrients can also stress the birds due to their heat increment, with protein having the highest value, and thus affect the birds' performance negatively. Energy and protein are the two main constituents that affect all production parameters in broiler chickens (Coillin et al., 2003; Kamran et al., 2008b). Energy is required for body functioning and protein is essential constituent of all animal body tissue. It is a widely acceptable principle in poultry nutrition that dietary energy and essential nutrient must be considered as an entity and in a right proportion for optimum growth of the birds (Jafarnejad and Sadegh, 2011). Studies have been carried out to define the minimum protein requirement for optimum growth rate in relation to energy level (Fetuga, 1984; NRC, 1994; Kamran, et al., 2004; Aviagen, 2009). The recommended amounts of energy and protein in broiler breeding guide books are high. Therefore providing recommended energy and proteins values increases feed prices which are not economically viable for poultry units (Bahreiny et al., 2013). Farmers try to reduce cost per unit products by reducing the amount of energy and protein in the feed. It is commonly agreed that greater performance in chicks can be achieved if essential amino acids (EAA) in low crude protein diet were equivalent to those needed in the recommended protein diet (Ciftci and Ceylon, 2004; Abdel - Maksoud et al., 2010). Increasing dietary metabolizable energy (ME) significantly increases the body weight gain (Zaman et al., 2008), reduces feed intake and improves feed conversion (Nogueira et al., 2013). Kamran et al. (2008a) observed that the reduction in dietary crude protein (CP) and metabolizable energy (ME) content leads to a linear increase in feed intake while weight gain and feed conversion ratio (FCR) are adversely affected. However, other authors observed that dilution of ME and CP of diet did not affect intake (Nawaz et al., 2006), live weight, FCR and protein efficiency ratio (PER) (Dairo et al., 2010).

Advancement in breeding, genetic improvement and changes in the climatic and other environmental conditions calls for a constant re-evaluation of broilers SD and their nutrient requirements. This study was carried out to examine the effect of varying stocking density, energy and protein levels and their interaction on the growth performances and feed economy of broiler chicken raised during late wet season in Nigeria.

\section{MATERIALS AND METHODS}

\section{Study area}

The experiment was conducted at the poultry unit of the University of Ibadan, Ibadan, Nigeria, Teaching and Research farm, from September to November.

\section{Experimental Design}

The experimental design was a complete randomized design in a factorial arrangement of $3 \times 2 \times 3$, with three energy (EM) levels, two crude protein (CP) levels, and three stocking densities (SD).

\section{Experimental Diets Formulation}

The recommended energy level for Arbor Acre commercial broiler starter phase (3080 kcal $/ \mathrm{kg} \mathrm{ME})$ and finisher phase (3200 kcal/kg ME) (Aviagen, 2009) were varied with $5 \%$ above and below to give three energy levels while the recommended protein levels of $23 \%$ and $20 \%$ for starter and finisher phase respectively where lowered by $5 \%$. Diets were formulated using each of the three energy levels at the two protein levels to give six diets (Table 1 and 2).

\section{Stocking Densities}

The recommended stocking density of 12 birds $/ \mathrm{m}^{2}$ for Arbor Acre commercial broiler strain raised in open sided house (Aviagen, 2009) was varied with $20 \%$ above and below to give three stocking densities of 10,12 and 14 birds per meter square respectively.

\section{Experimental Birds}

Six hundred and twelve (612) one-day-old Arbor Acre broilers were obtained from Ajanla Hatchery, Ibadan, Oyo State, Nigeria. The birds were weighed and randomly distributed to six brooding units of 102 birds/unit. At the end of day seven, 576 (96 per unit) birds were assigned to the various stocking densities at the rate of eight birds per interaction unit with four replicates each. The experiment lasted for 56 days.

\section{Housing and management of birds}

Birds were housed in an open sided house with $32 \mathrm{~cm}$ dwarf wall, with the inside partitioned according to the stocking density with $0.05 \mathrm{~m}^{2} /$ bird provided for feeder and drinker in each partition. Hanging feeder and an-eightliter water bowl of $30 \mathrm{~cm}$ diameter were provided for each partition from week three. The floor was covered with $6 \mathrm{~cm}$ high wood shaving litters, the litter materials were changed at $4^{\text {th }}$ and $6^{\text {th }}$ week. Thermo hygrometers were placed at strategic points in the house to monitor 
Table 1. Composition of the starter experimental diets for broilers

\begin{tabular}{lcccccc}
\hline \multirow{2}{*}{ Ingredient } & \multicolumn{7}{c}{ DIETS } \\
\cline { 2 - 7 } & RCP-RME & LCP-RME & RCP-LME & LCP-LME & RCP-HME & LCP- HME \\
\hline Maize & 49.00 & 52.00 & 55.00 & 56.00 & 52.15 & 54.35 \\
Wheat offal & 5.00 & 5.00 & 4.65 & 5.00 & 0 & 0 \\
FFSB & 8.65 & 8.00 & 5.00 & 7.12 & 9.50 & 9.50 \\
GNC & 25.00 & 23.00 & 25.00 & 22.00 & 23.5 & 22.00 \\
Fish Meal & 4.00 & 3.55 & 5.00 & 4.50 & 5.00 & 4.50 \\
Palm oil & 3.00 & 3.00 & 0 & 0 & 4.50 & 4.30 \\
Bone Meal & 3.00 & 3.00 & 3.00 & 3.00 & 3.00 & 3.00 \\
Oyster shall & 1.50 & 1.50 & 1.50 & 1.50 & 1.50 & 1.50 \\
Salt [NaCl] & 0.25 & 0.25 & 0.25 & 0.25 & 0.25 & 0.25 \\
Broiler Premix & 0.25 & 0.25 & 0.25 & 0.25 & 0.25 & 0.25 \\
DL-Meth: & 0.10 & 0.11 & 0.10 & 0.10 & 0.10 & 0.10 \\
L-Lysine & 0.25 & 0.34 & 0.25 & 0.28 & 0.25 & 0.25 \\
Total & 100 & 100 & 100 & 100 & 100 & 100 \\
& & & & & & \\
Determined Nutrients & & & & & & \\
Crude Protein & 23.03 & 21.74 & 23.40 & 21.92 & 23.13 & 21.80 \\
ME[keal/kg] & 3106 & 3112 & 2928 & 2933 & 3217 & 3220 \\
& & & & & & \\
Calculated Nutrients & & & & & & \\
L-Lysine & 1.20 & 0.20 & 1.20 & 1.20 & 1.20 & 1.20 \\
DL -Meth: & 0.45 & 0.45 & 0.46 & 0.45 & 0.46 & 0.45 \\
Cal;Pr & 135 & 143 & 125 & 134 & 139 & 148 \\
Ca & 1.93 & 1.90 & 1.99 & 1.96 & 1.99 & 1.95 \\
Avail. P & 0.71 & 0.70 & 0.71 & 0.71 & 0.67 & 0.66 \\
\hline
\end{tabular}

RCM-RME, Recommended protein \&energy; LCP-RME, Lower protein \& Recommended energy; RCP-LME, Recommended protein \& lower energy; LCP-LME, Lower protein \&lower energy; RCP-HME, Recommended protein \& higher energy; LCP-HME, Lower protein \& high energy; FFSB, Full fat soya bean; GNC, Ground nut cake; Ca, Calcium; Avail. P, Available Phosphorus.

temperature and humidity.

Vaccination and medication were administered as recommended by the hatchery operator. Feed and water were supplied ad libitum. Records of feed intake and birds' weight were taken weekly, while mortality record was taken daily. The following parameters were calculated; feed intake (FI, g), weight gain (WG, g) feed conversion ratio (FCR), survival rate (SR, \%), and live weight per area $\left(\mathrm{LW} / \mathrm{m}^{2}\right)$, feed cost per kglive weight (FC/kglw) and feed cost per dressed weight (FC/kgdw).

\section{Carcass Yield Evaluation}

At the end of week eight, 18 birds per stocking density (equivalent to 19 birds per diet) with weight close to the average of the group were selected, fasted over night, sacrificed, scalded in hot water, defeathered and eviscerated. The prima cuts and abdominal fat were separated, weighed and expressed as percentage of live weight, (Shahin and Elazeem, 2005).

\section{Statistical Analysis}

Data generated where subjected to analysis of variance (ANOVA) using General Linear Model (GLM) of SAS Software 9.2 (SAS 2008). Significantly different means were separated using Duncan Multiple Range (DMR) test, with level of significance set at $p<0.05$.

\section{RESULTS}

The mean temperature and relative humidity of the poultry house were $27.8{ }^{\circ} \mathrm{C}$ and $75.47 \%$, respectively.

The interaction EM $\times$ CP levels $\times$ SD affected the feed intake and the highest value was obtained using diets with low EM and CP levels (Table 3) Treatments did not affect $(p>0.05)$ the survival rate, however, SD at $12 \mathrm{birds} / \mathrm{m}^{2}$ resulted in the best values $(p<0.05)$ of FLW (2272.21g), WG (2230.71g) and FCR (2.10) and the use of diet with lower CP and EM increased $(p<0.05)$ FLW (2353.42g) and WG (2312.42g), but the best values for FCR were obtained with diets with recommended CP and 
Table 2. Compositions of the finisher experimental diets for broilers

\begin{tabular}{|c|c|c|c|c|c|c|}
\hline \multirow{2}{*}{ Ingredient } & \multicolumn{5}{|c|}{ DIETS } & \multirow[b]{2}{*}{ LCP-HME } \\
\hline & RCP-RME & LCP-RME & RCP-LME & LCP-LME & RCP-HME & \\
\hline Maize & 58.50 & 59.00 & 58.50 & 59 & 59.74 & 60.68 \\
\hline Wheat offal & 2.00 & 3.30 & 5.04 & 6.00 & 0 & 0 \\
\hline FFSB & 15.40 & 16.07 & 12.00 & 12.00 & 18.00 & 18.00 \\
\hline GNC & 15.00 & 12.50 & 17.50 & 16.02 & 12.00 & 11.00 \\
\hline Palm oil & 3.81 & 3.80 & 1.60 & 1.6 & 5.00 & 5.00 \\
\hline Bone Meal & 3.00 & 3.00 & 3.00 & 3.00 & 3.00 & 3.00 \\
\hline Oyster shall & 1.50 & 1.50 & 1.50 & 1.50 & 1.50 & 1.50 \\
\hline Salt [NaCl] & 0.25 & 0.25 & 0.25 & 0.25 & 0.25 & 0.25 \\
\hline Broiler Premix & 0.25 & 0.25 & 0.25 & 0.25 & 0.25 & 0.25 \\
\hline DL -Meth: & 0.11 & 0.13 & 0.11 & 0.13 & 0.11 & 0.12 \\
\hline L-Lysine & 0.18 & 0.20 & 0.25 & 0.25 & 0.15 & 0.20 \\
\hline Total & 100 & 100 & 100 & 100 & 100 & 100 \\
\hline \multicolumn{7}{|c|}{ Determined Nutrients } \\
\hline Crude Protein & 20.11 & 19.01 & 20.24 & 19.14 & 20.29 & 19.00 \\
\hline ME[kcal/kg] & 3231 & 3235 & 3096 & 3095 & 3356 & 3362 \\
\hline \multicolumn{7}{|c|}{ Calculated Nutrients } \\
\hline L-Lysine & 1.04 & 1.01 & 1.03 & 0.02 & 1.00 & 1.02 \\
\hline DL -Meth: & 0.40 & 0.41 & 0.40 & 0.41 & 0.40 & 0.41 \\
\hline Cal;Pr & 161 & 170 & 153 & 162 & 165 & 177 \\
\hline $\mathrm{Ca}$ & 1.68 & 1.68 & 1.68 & 1.68 & 1.68 & 1.68 \\
\hline Avail. P & 0.63 & 0.64 & 0.65 & 0.66 & 0.61 & 0.61 \\
\hline
\end{tabular}

RCM-RME, Recommended protein \&energy; LCP-RME, Lower protein \& Recommended energy; RCP-LME, Recommended protein \& lower energy; LCP-LME, Lower protein \&lower energy; RCP-HME, Recommended protein \& higher energy; LCP-HME, Lower protein \& high energy; FFSB, Full fat soya bean; GNC, Ground nut cake; Ca, Calcium; Avail. P, Available Phosphorus.

high EM, and lower CP and high EM (Table 4).

The carcass yield was affected $(p<0.05)$ by the interaction EM $\times$ CP levels $\times \mathrm{SD}$, with the lowest value $(67.33 \%)$ found with birds raised under SD at 10 birds $/ \mathrm{m}^{2}$ and diets with lower CP and recommended EM evels (Table 5).

The use of SD12 birds $/ \mathrm{m}^{2}$ caused a reduction $(\mathrm{p}<.05)$ on the back cut $(14.22 \%)$ compared to the use of 14 birds $/ \mathrm{m}^{2}(15.33 \%)$. The diets with low CP and EM, low $\mathrm{CP}$ and recommended $\mathrm{EM}$, and recommended $\mathrm{CP}$ and low $E M$, decreased $(p<0.05)$ abdominal fat relative weight (Table 6).

The lowest live weight and carcass weight per square meter $(p<0.05)$ were observed with SD at 10 birds $/ \mathrm{m}^{2}$, while lowest feed cost per kilogram of live weight and per kilogram of carcass weight were obtained with SD $12 \mathrm{birds} / \mathrm{m}^{2}$. Carcass weight per square meter and feed cost per carcass weight were not affected $(p>0.05)$ by the $\mathrm{CP}$ and EM levels, however, diets with recommended CP and energy levels resulted in lower $(p<0.05)$ live weight per square meter. Diets with recommended CP and EM levels, and low CP and recommended EM increased $(p<0.05)$ the feed cost per live weight (Table 7).

\section{Discussion}

Birds raised under the recommended SD (12 birds $/ \mathrm{m}^{2}$ ) had the best $(p<0.05)$ productive performance. Birds on the higher density might not have been able to liberate enough heat for optimum growth, since adequate feed intake and uninterrupted emission of heat are necessary for intensive growth rate (Yadgari et al., 2006), and birds under the lower stocking density (10birds $/ \mathrm{m}^{2}$ ) must have wasted energy for growth on excessive exercise. The lack of the effect $(p>0.05)$ on the FI agrees with the observation of Beloor et al. (2010) and is probably due to the sumptuous feeding and drinking space provided $(0.24 \mathrm{~m})$ per bird in all the stocking densities. Insufficient feeding space has been attributed to be the cause of reduced FI at high SD (Estevez et al., 2007; Simsek et al., 2009). In consonance with most authors (Ravindran et al., 2006; Buijs, et al., 2009, Sekeroglu et al., 2011) there was no statistical dependence $(p>0.05)$ of survival rate on SD, $(p>0.05)$. The diet with lower energy and protein levels had the highest $(p<0.05) \mathrm{FI}, \mathrm{FLW}$ and WG $(p<0.05)$. This was in agreement with the observation of Bregendahl et al. (2002) who found significant increase in 
Table 3. Effect of the interaction among stocking density, energy and crude protein levels on growth performance of broilers at 56 days of age, during the late wet season.

\begin{tabular}{|c|c|c|c|c|c|c|}
\hline $\mathrm{SD}\left(\mathrm{bird} / \mathrm{m}^{2}\right)$ & DIETS & FLW (g) & WG (g) & $\mathrm{FI}(\mathrm{g})$ & FCR & SR (\%) \\
\hline \multirow{6}{*}{10} & RCP-RME & 2099.60 & 2058.60 & $4708.51^{\text {cde }}$ & 2.24 & 96.88 \\
\hline & LCP-RME & 2081.50 & 2039.5 & $4682.00^{\text {de }}$ & 2.26 & 93.75 \\
\hline & RCP-LME & 2173.00 & 2132.00 & $4758.79^{\mathrm{bcd}}$ & 2.20 & 93.75 \\
\hline & LCP-LME & 2292.50 & 2251.50 & $5172.43^{a}$ & 2.26 & 100.00 \\
\hline & RCP-HME & 2265.00 & 2223.00 & $4608.73^{\text {de }}$ & 2.03 & 93.75 \\
\hline & LCP-HME & 2239.50 & 2197.50 & $4426.33^{e}$ & 1.98 & 93.75 \\
\hline \multirow{6}{*}{12} & RCP-RME & 2272.50 & 2231.50 & $5010.81^{a b c}$ & 2.21 & 96.88 \\
\hline & LCP-RME & 2232.50 & 2190.50 & $4854.26^{\mathrm{bcd}}$ & 2.18 & 100.00 \\
\hline & RCP-LME & 2175.50 & 2134.50 & $4659.45^{\text {de }}$ & 2.14 & 100.00 \\
\hline & LCP-LME & 2429.50 & 2388.50 & $5084.82^{\mathrm{ab}}$ & 2.10 & 96.88 \\
\hline & $\mathrm{RCP}-\mathrm{HME}$ & 2232.00 & 2190.00 & $4414.35^{\mathrm{e}}$ & 1.98 & 96.88 \\
\hline & LCP-HME & 2291.25 & 2249.25 & $4601.95^{\text {de }}$ & 2.01 & 96.88 \\
\hline \multirow{7}{*}{14} & RCP-RME & 2028.00 & 1987.00 & $4516.72^{\mathrm{de}}$ & 2.23 & 93.75 \\
\hline & LCP-RME & 2131.25 & 2089.25 & $4849.51^{\mathrm{bcd}}$ & 2.28 & 96.88 \\
\hline & RCP-LME & 2092.75 & 2051.75 & $4623.39^{d e}$ & 2.21 & 100.00 \\
\hline & LCP-LME & 2338.25 & 2297.25 & $5191.28^{a}$ & 2.22 & 93.75 \\
\hline & RCP-HME & 2225.00 & 2183.00 & $4730.94^{\mathrm{cd}}$ & 2.13 & 90.63 \\
\hline & LCP-HME & 2180.00 & 2138.00 & $4677.53^{\mathrm{de}}$ & 2.15 & 100.00 \\
\hline & SEM & 16.53 & 16.53 & 34.10 & 0.015 & 3.92 \\
\hline
\end{tabular}

a,b,c,d,e: Means on the same row with different superscripts are significantly different $(p<0.05)$. RCM-RME, Recommended protein \&energy; LCP-RME, Lower protein \& Recommended energy; RCP-LME, Recommended protein \& lower energy; LCP-LME, Lower protein \& lower energy; RCP-HME, Recommended protein \& higher energy; LCP-HME, Lower protein \& high energy; SEM, Standard error of means; SD, stocking density; FLW, final live weight WG, weight gain; $\mathrm{Fl}$, feed intake; FCR, feed conversion ratio; SR, survival rate.

Table 4. Effect of stocking density, energy and crude protein levels on growth performance of broilers at 56 days of age during late wet season.

\begin{tabular}{lccccc}
\hline SD $\left(\mathbf{b i r d} / \mathbf{m}^{2}\right)$ & FLW $(\mathbf{g}) / \mathbf{b i r d} / \mathbf{5 6 d a y s}$ & $\mathbf{W G} \mathbf{( g )}$ & $\mathbf{F I} \mathbf{( g ) / b i r d / 5 6 d a y s}$ & $\mathbf{F C R}$ & SR $(\%)$ \\
\hline 10 & $2186.16^{\mathrm{b}}$ & $2146.68^{\mathrm{b}}$ & 4725.11 & $2.16^{\mathrm{a}}$ & 95.31 \\
12 & $2272.21^{\mathrm{a}}$ & $2230.71^{\mathrm{a}}$ & 4771.11 & $2.10^{\mathrm{b}}$ & 97.92 \\
14 & $2171.87^{\mathrm{b}}$ & $2130.35^{\mathrm{b}}$ & 4775.68 & $2.20^{\mathrm{a}}$ & 95.83 \\
SEM & 16.53 & 16.53 & 34.1 & 0.01 & 1.6 \\
& & & & & \\
Diet & & & & & \\
REC-RME & $2139.33^{\mathrm{b}}$ & $2098.33^{\mathrm{b}}$ & $4761.33^{\mathrm{cb}}$ & $2.23^{\mathrm{a}}$ & 95.83 \\
LCP-RME & $2148.42^{\mathrm{b}}$ & $2106.42^{\mathrm{b}}$ & $4795.26^{\mathrm{b}}$ & $2.24^{\mathrm{a}}$ & 96.88 \\
LCP-LME & $2147.08^{\mathrm{b}}$ & $2106.08^{\mathrm{b}}$ & $4680.54^{\mathrm{bcd}}$ & $2.19^{\mathrm{a}}$ & 97.92 \\
LCP-LME & $2353.42^{\mathrm{a}}$ & $2312.42^{\mathrm{a}}$ & $5149.51^{\mathrm{a}}$ & $2.19^{\mathrm{a}}$ & 96.88 \\
RCP-HME & $2240.67^{\mathrm{b}}$ & $2198.67^{\mathrm{b}}$ & $4584.34^{\mathrm{cd}}$ & $2.05^{\mathrm{b}}$ & 93.75 \\
LCP-HME & $2237.92^{\mathrm{b}}$ & $2194.92^{\mathrm{b}}$ & $4568.61^{\mathrm{d}}$ & $2.04^{\mathrm{b}}$ & 96.88 \\
SEM & 33.26 & 33.26 & 34.1 & 0.03 & 2.26 \\
\hline
\end{tabular}

$a, b, c$, Means on the same row with different superscripts are significantly different $(p<0.05)$. RCM-RME- Recommended protein \&energy; LCP-RME, Lower protein \& Recommended energy; RCP-LME, Recommended protein \& lower energy; LCP-LME, Lower protein \&lower energy; RCP-HME, Recommended protein \& higher energy; LCP-HME, Lower protein \& high energy. SEM, Standard error of means; SD, stocking density; FLW, final live weight; WG, weight gain; FI, feed intake; FCR, feed conversion ratio; SR, survival rate. 
Table 5: Effect of the interaction among stocking density, energy and protein levels on carcass traits of broilers chicken during late wet season

\begin{tabular}{|c|c|c|c|c|c|c|c|c|}
\hline \multirow{2}{*}{ SD (birds/m²) } & \multirow{2}{*}{ DIET } & \multirow{2}{*}{ DW (\%) } & \multicolumn{5}{|c|}{ Prime cuts (\%) } & \multirow{2}{*}{ AF (\%) } \\
\hline & & & TH & DS & BR & BK & WNG & \\
\hline \multirow{6}{*}{10} & RCP-RME & $73.67^{a b c}$ & 12 & 11.67 & 18.33 & 15.33 & 8.00 & 2.00 \\
\hline & LCP-RME & $67.33^{\mathrm{e}}$ & 10.67 & 10.33 & 17.00 & 14.67 & 7.67 & 2.67 \\
\hline & RCP-LME & $71.67^{\mathrm{abcd}}$ & 11.67 & 11.00 & 19.33 & 15.00 & 7.33 & 1.67 \\
\hline & LCP-LME & $70.67^{\mathrm{cd}}$ & 10.67 & 11.00 & 18.00 & 15.00 & 7.67 & 2.00 \\
\hline & RCP-HME & $73.40^{\mathrm{abcd}}$ & 11.33 & 11.00 & 19.33 & 15.33 & 8.00 & 3.23 \\
\hline & LCP-HME & $73.67^{c d}$ & 11.33 & 10.67 & 20.67 & 15.00 & 8.00 & 3.23 \\
\hline \multirow{6}{*}{12} & RCP-RME & $74.33^{a}$ & 11.67 & 11.00 & 19.33 & 14.33 & 8.33 & 2.88 \\
\hline & LCP-RME & $72.67^{\mathrm{abcd}}$ & 11.33 & 11.00 & 18.33 & 14.67 & 7.67 & 3.07 \\
\hline & RCP-LME & $73.43^{\mathrm{abcd}}$ & 12.33 & 10.67 & 19.67 & 14.33 & 7.67 & 2.54 \\
\hline & LCP-LME & $73.33^{\mathrm{abcd}}$ & 10.67 & 10.00 & 20.00 & 14.67 & 7.33 & 2.20 \\
\hline & RCP-HME & $70.50^{\mathrm{abcd}}$ & 11.33 & 11.00 & 18.67 & 12.00 & 8.33 & 2.50 \\
\hline & LCP-HME & $71.07^{\mathrm{bcd}}$ & 10.33 & 10.33 & 20.00 & 15.33 & 7.00 & 2.51 \\
\hline \multirow{7}{*}{14} & RCP-RME & $72.93^{\mathrm{abcd}}$ & 11.33 & 11.33 & 18.00 & 14.67 & 7.67 & 2.91 \\
\hline & LCP-RME & $72.67^{\mathrm{abcd}}$ & 11.33 & 11.67 & 17.67 & 15.00 & 8.00 & 1.82 \\
\hline & RCP-LME & $73.50^{\mathrm{abcd}}$ & 12.00 & 11.00 & 18.33 & 16.33 & 8.00 & 2.38 \\
\hline & LCP-LME & $73.83^{\mathrm{ab}}$ & 11.33 & 11.00 & 19.33 & 15.67 & 8.00 & 2.06 \\
\hline & RCP-HME & $71.00^{\mathrm{bcd}}$ & 11.00 & 11.00 & 17.33 & 15.00 & 8.00 & 2.43 \\
\hline & LCP-HME & $73.67^{\mathrm{abc}}$ & 11.67 & 10.33 & 20.00 & 15.33 & 8.67 & 2.93 \\
\hline & SEM & 1.06 & 0.51 & 0.42 & 1.21 & 0.75 & 0.28 & 0.36 \\
\hline
\end{tabular}

$a, b, c, d$, Means on the same row with different superscripts are significantly different $(p<0.05)$. RCP-RME, Recommended protein \&energy; LCP-RME, Lower protein \& Recommended energy; RCP-LME, Recommended protein \& lower energy; LCP-LME, Lower protein \&lower energy; RCP-HME, Recommended protein \& higher energy; LCP-HME, Lower protein \& high energy; SEM, Standard error of means; SD, stocking density; DW, dressed weight; TH, thigh; DS, drum stick; BK, back; WNG, wing; AF, abdominal fat.

Table 6: Effects of stocking density, energy and protein levels on carcass traits of broilers at 56 days of age, raised during late wet season.

\begin{tabular}{lcccccccc}
\hline \multirow{2}{*}{ SD (bird/m2) } & \multirow{2}{*}{ LW (g) } & \multirow{2}{*}{ DW (\%) } & \multicolumn{7}{c}{ Prime cuts (\%) } \\
\cline { 5 - 9 } & & & TH & DS & BR & BK & WNG & AF (\%) \\
\hline 10 & 2086.11 & 71.73 & 11.28 & 10.94 & 18.78 & $15.06 \mathrm{ab}$ & 7.78 & 2.47 \\
12 & 2188.89 & 72.56 & 11.28 & 10.67 & 19.33 & $14.22 \mathrm{~b}$ & 7.72 & 2.62 \\
14 & 2044.44 & 73 & 11.44 & 11.06 & 18.44 & $15.33 \mathrm{a}$ & 8.06 & 2.42 \\
SEM & 43.686 & 0.434 & 0.208 & 0.173 & 0.494 & 0.304 & 0.116 & 0.148 \\
Diet & & & & & & & & \\
RCP-RME & 2061.11 & $73.64^{\mathrm{a}}$ & $11.67^{\mathrm{ab}}$ & $11.33^{\mathrm{a}}$ & $18.56^{\mathrm{ab}}$ & 14.78 & 8.00 & $2.60^{\mathrm{ab}}$ \\
LCP-RME & 2077.78 & $70.89^{\mathrm{c}}$ & $11.11^{\mathrm{ab}}$ & $11.00^{\mathrm{ab}}$ & $17.67^{\mathrm{b}}$ & 14.78 & 7.78 & $2.52^{\mathrm{ab}}$ \\
RCP-LME & 2022.22 & $72.87^{\mathrm{ab}}$ & $12.00^{\mathrm{a}}$ & $10.89^{\mathrm{ab}}$ & $19.11^{\mathrm{ab}}$ & 15.22 & 7.67 & $2.20^{\mathrm{b}}$ \\
LCP-LME & 2205.56 & $72.61^{\mathrm{abc}}$ & $10.89^{\mathrm{c}}$ & $10.67^{\mathrm{ab}}$ & $19.10^{\mathrm{ab}}$ & 15.11 & 7.67 & $2.09^{\mathrm{b}}$ \\
LCP-HME & 2111.11 & $71.63^{\mathrm{bc}}$ & $11.22^{\mathrm{ab}}$ & $11.00^{\mathrm{ab}}$ & $18.44^{\mathrm{ab}}$ & 14.11 & 8.10 & $2.7^{\mathrm{ab}}$ \\
RCP-HME & 2161.11 & $72.80^{\mathrm{ab}}$ & $11.11^{\mathrm{ab}}$ & $10.44^{\mathrm{c}}$ & $20.22^{\mathrm{a}}$ & 15.22 & 7.89 & $2.89 \mathrm{a}$ \\
SEM & 61.781 & 0.164 & 0.294 & 0.244 & 0.698 & 0.43 & 0.164 & 0.21 \\
\hline
\end{tabular}

a,b,c, Means on the same row with different superscripts are significantly different $(p<0.05)$. RCP-RME, Recommended protein \&energy; LCP-RME, Lower protein \& Recommended energy; RCP-LME, Recommended protein \& lower energy; LCP-LME, Lower protein \&lower energy; RCP-HME, Recommended protein \& higher energy; LCP-HME- Lower protein \& high energy; SEM, Standard error of means ; SD, stocking density; LW, live weights; DW, dressed weight; TH, thigh; DS, drum stick; BK, back; WNG, wing; AF, abdominal fat. 
Table7. Effect of stocking density, energy and protein levels on meat production per square meter and feed economy of broilers at 56 days of age raised during late wet season.

\begin{tabular}{lcccc}
\hline SD $\left(\mathbf{b i r d} / \mathbf{m}^{\mathbf{2}}\right)$ & $\mathbf{L W} / \mathbf{m}^{\mathbf{2}} \mathbf{( \mathbf { k g } )}$ & $\mathbf{D W} / \mathbf{m}^{\mathbf{2}} \mathbf{( \mathbf { k } )}$ & $\mathbf{F C} / \mathbf{L W} \mathbf{( \$ )}$ & FC/DW (\$) \\
\hline 10 & $20.85^{\mathrm{c}}$ & $14.40^{\mathrm{c}}$ & $214.21^{\mathrm{a}}$ & $314.94^{\mathrm{a}}$ \\
12 & $26.73^{\mathrm{b}}$ & $18.91^{\mathrm{b}}$ & $208.17^{\mathrm{b}}$ & $296.21^{\mathrm{b}}$ \\
14 & $29.14^{\mathrm{a}}$ & $20.65^{\mathrm{a}}$ & $218.60^{\mathrm{a}}$ & $323.02^{\mathrm{a}}$ \\
SEM & 0.52 & 0.53 & 1.86 & 7.68 \\
& & & & \\
Diet & & & & \\
RCP-RME & $24.55^{\mathrm{b}}$ & 17.68 & $223.40^{\mathrm{a}}$ & 310.18 \\
LCP-RME & $25.08^{\mathrm{a}}$ & 17.13 & $222.38^{\mathrm{a}}$ & 330.25 \\
RCP-LME & $25.27^{\mathrm{a}}$ & 17.33 & $205.54^{\mathrm{b}}$ & 304.85 \\
LCP-LME & $27.27^{\mathrm{a}}$ & 19.23 & $205.30^{\mathrm{b}}$ & 300.36 \\
RCP-HME & $25.18^{\mathrm{a}}$ & 17.79 & $213.15^{\mathrm{b}}$ & 320.45 \\
LCP-HME & $26.09^{\mathrm{a}}$ & 18.75 & $212.20^{\mathrm{b}}$ & 302.25 \\
SEM & 0.73 & 0.75 & 2.64 & 10.87 \\
\hline
\end{tabular}

a,b,c, Means on the same row with different superscripts are significantly different $(p<0.05)$. RCP-RME, Recommended protein \&energy; LCP-RME-Lower protein \& Recommended energy; RCP-LMERecommended protein \& lower energy; LCP-LME, Lower protein \&lower energy; RCP-HME- Recommended protein \& higher energy; LCP-HME, Lower protein \& high energy; SEM, Standard error of means; SD, stocking density; $\mathrm{LW} / \mathrm{m}^{2}$, live weight per meter square; $\mathrm{DW} / \mathrm{m}^{2}$, dressed weight per meter square; $\mathrm{FC} / \mathrm{LW}$, feed cost per live weight; FC/DW, feed cost per dressed weight.

FI by broiler chicks fed on diet with $20 \%$ CP supplemented with amino acids, compared to the ones fed with $23 \%$ CP diet, and the report of Abdel-Maksoud et al. (2010) that high dietary protein reduces FI. Other authors (Kamran et al., 2004; Nawaz et al., 2006) noted that dilution of $\mathrm{ME}$ and $\mathrm{CP}$ in the diet did not affect FI. In consonance with the highest FLW and WG by birds fed low EM and CP in this work, Abdel-Maksoudet al. (2010) verified that birds fed $21 \% \mathrm{CP}$ supplemented with essential amino acids showed the highest body weight compared to other treatments $(23 \% \mathrm{CP}$ not supplemented, $19 \% \mathrm{CP}$ supplemented and $21 \%$ not supplemented with amino acids). However, in contrast to this result, Leeson et al. (1996), Kamran et al. (2008a), (2008b) mentioned that reduction in dietary CP and ME content leads to a linear increase in $\mathrm{FI}$, while $\mathrm{WG}$ and FCR were adversely affected. The improved $(p<0.05) \mathrm{FI}$ and WG by birds on low EM and CP diet could be due to the reduced heat increment, which was associated with the metabolism of excess protein. Reduced heat increment leads to reduced heat stress and therefore improved $\mathrm{FI}$ and WG. Birds on high EM and normal $\mathrm{CP}$, and high EM and lower CP had the lower FI and FCR. This agreed with the observation of Waldroup et al. (1976) and Skinner et al. (1992) that increasing nutrient density leads to a significant reduction in feed consumption. Additionally, Nahashon et al. (2005) and Elmansy (2006) showed that FCR was improved with increasing energy level during the finishing period. This is as a result of the lower percentage of reduction in WG (4.92\% and $5.08 \%$ for high EM and recommended CP and, high EM low CP respectively, when compared with the reduction in $\mathrm{FI}(11 \%$ and $11.28 \%$ with the same diet) in contrast with low EM and CP diet.

The result of this study shows that the dietary energy levels were sufficient to supply the broilers requirements for thermoregulation and growth and did not result in any carcass or parts loss. Dressing percentage of thigh, drumstick, breast and abdominal fat were not influenced by SD, and this was in agreement with the observation of Thomas et al. (2004) and Ravindran et al. (2006) that there is no difference in relative weight of breast and abdominal fats in birds raised on different SD ( $5,10.15$ and.20 birds per $\mathrm{m}^{2}$ ). In a similar work, Dozier et al. (2005) reported no difference in relative weight of carcass and abdominal fat due to SD. However, El- Deek and Al-Harthi (2004) verified effect of SD on dressing and hind part percentage, which decreased when broilers were stocked at 18 birds $/ \mathrm{m}^{2}$ compared to those stocked at $14 \mathrm{birds} / \mathrm{m}^{2}$, while those on $10 \mathrm{birds} / \mathrm{m}^{2}$ showed intermediate percentage dressing and hind part and a significantly higher abdominal fat percentage.

Dietary energy level did not affect $(p>0.05)$ the percentage of dressed weight and breast meat, and this agrees with the conclusion of Rosa et al. (2007) that higher dietary energy level did not affect the percentage of dressed weight, breast and wing yields. This finding contrasts with the observation of Nguyen et al. (2010) that higher dietary energy significantly increased carcass weight and abdominal fat, but decreased wing and legs yield.

Dilution of both energy and protein did not negatively depress percentage of dressed weight, drumstick, breast, back and wing yield, as opposed to the linearly decreased 
carcass weight and breast yield of male broiler, as diet was diluted for both energy and protein observed by Lesson et al. (1996).

Increase or decrease of either energy or protein did not affect $(p>0.05)$ the percentage of thigh, except when both protein and energy were diluted, also increasing energy and dilution of protein depresses more percentage of drumstick than dilution of both. Inessence, the hind limb requires relative high and balance levels of both energy and protein.

The abdominal fat content was highest for diet with the highest energy level and lowest for diet with lowest energy level. This was consistent with Summers et al. (1992) and Boekholt et al. (1994) who found a reduction in fat deposition due to a decrease in dietary energy because excess energy is converted and deposited as fat. The lowest percentage of dressed weight at SD 10 birds $/ \mathrm{m}^{2}$ and low CP and recommend EM could be due to the lowest FLW and WG shown by this group. As expected, there was an increase in meat production per area $\left(\mathrm{kg} / \mathrm{m}^{2}\right)$ as a function of SD. This was in agreement with the other authors (Tong et al., 2012; Nogueira et al., 2013).

The feed cost per live weight was affected $(p<0.05)$ by $\mathrm{SD}$, with the result following the trend of FLW and WG. Birds on SD 14 birds $/ \mathrm{m}^{2}$ had the lower FLW and WG and the highest feed cost per live weight and dressed weight not differing from SD 10 birds $/ \mathrm{m}^{2}$, but significantly higher than that of $12 \mathrm{birds} / \mathrm{m}^{2}$. However, considering the gross profitability per unit space, using monetary returns per meter square minus cost of feed on yield per meter square (Puron et al., 1995) birds on SD 12 birds $/ \mathrm{m}^{2}$ had the highest value. The feed cost per live weight was affected by FI, WG and feed cost. While birds on diet with higher energy ate less than birds on lower energy, they had a relatively higher weight gain, thus, the higher feed cost was nullified by the gain, while the feed cost $/ \mathrm{kg}$ live weight between birds on high and low energy. Birds on low EM and CP had the highest gross profit on feed/unit weight and area.

\section{Conclusion}

Broiler chickens may be economically raised at stocking density $12 \mathrm{birds} / \mathrm{m}^{2}$ and on diet containing $2933 \mathrm{kcal} / \mathrm{kgME}$ and $21.92 \%$ crude protein for starter phase and 3095 $\mathrm{kcal} / \mathrm{kgME}$ and $19.14 \%$ crude protein for finisher phase, during late wet season in South Western Nigeria.

\section{CONFLICT OF INTEREST}

The authors declare that they have no conflict of interest.

\section{REFERENCES}

Abdel-Maksoud, A., Yan, F., Cerrate, S., Coto, C., Wang, Z., \&
Waldroup, P. W. (2010). Effect of dietary crude protein, lysine level and amino acid balance on performance of broilers 0 to 18 days of age. International Journal of Poultry Science, 9(1), 21-27.

Abudabos, A. M., Samara, E. M., Hussein, E. O., Mu'ath, Q., \& Al-Atiyat, R. M. (2013). Impacts of stocking density on the performance and welfare of broiler chickens. Italian Journal of Animal Science, 12(1), 11.

Sekeroglu, A., Sarica, M., Gulay, M. S., \& Duman, M. (2011). Effect of stocking density on chick performance, internal organ weights and blood parameters in broilers. Journal of Animal and Veterinary Advances, 10(2), 246-250.

Aviagen (2009).Arbor Acres plus broiler nutrition specification. www.Aviagen.com

Beloor, J., Kang, H. K., Kim, Y. J., Subramani, V. K., Jang, I. S., Sohn, S. H., \& Moon, Y. S. (2010). The effect of stocking density on stress related genes and telomeric length in broiler chickens. Asian-Australasian Journal of Animal Sciences, 23(4), 437-443.

Boekholt, H. A., Van Der Grinten, P. H., Schreurs, V. V. A. M., Los, M. J. N., \& Leffering, C. P. (1994). Effect of dietary energy restriction on retention of protein, fat and energy in broiler chickens. British poultry science, 35(4), 603-614.

Bregendahl, K., Sell, J. L., \& Zimmerman, D. R. (2002). Effect of low-protein diets on growth performance and body composition of broiler chicks. Poultry science, 81(8), 11561167.

Buijs, S., Keeling, L., Rettenbacher, S., Van Poucke, E., \& Tuyttens, F. A. M. (2009). Stocking density effects on broiler welfare: Identifying sensitive ranges for different indicators. Poultry Science, 88(8), 1536-1543.

Ciftci, I., \& Ceylan, N. (2004). Effects of dietary threonine and crude protein on growth performance, carcase and meat composition of broiler chickens. British poultry science, 45(2), 280-289.

Collin, A., Malheiros, R. D., Moraes, V. M., Van As, P., Darras, V. M., Taouis, M., Decuypere, E., \& Buyse, J. (2003). Effects of dietary macronutrient content on energy metabolism and uncoupling protein mRNA expression in broiler chickens. British Journal of Nutrition, 90(02), 261-269.

Dairo, F. A. S., Adesehinwa, A. O. K., Oluwasola, T. A., \& Oluyemi, J. A. (2010). High and low dietary energy and protein levels for broiler chickens. African Journal of Agricultural Research, 5(15), 2030-2038.

Dozier, W. A., Thaxton, J. P., Braihon, S. L., Morgan, G. W., Miles, D. M., Roush, W. B., Lott, B. D., Vizzier-Thaxton, Y. (2005). Effect of stocking on growth performance and processing yield of heavy broilers. Poultry Science. 84:13321338.

Dozier, W. A, Thaxton, J. P, Purswell, J. L, Olanrewaju, H. A, Branton, S. L, Roush, W. B. (2006). Stocking density effect on male broilers growth to 1.8 kilograms of BW. Poultry Science. 85:344-351.

Bahreiny, E., Dadvar, P., Morovat, M., \& Bujarpoor, M. (2013). Effect of different level of energy to protein ratio and breeding system on performance and carcass characteristics of male and female broilers. International Journal of Agriculture, 3(3), $597-607$.

El-Deek, A. A., \& Al-Harthi, M. A. (2004).Responses of modern broiler to stocking density green tea commercial multi enzymes and their interaction on productive performance, carcass characteristics. International Journal of Poultry Science, 3(10):635-645.

Elmansy, M. M. (2006). Assessment of the effect of L-carhitine 
supplementation to the diet with different dietary energy levels on broiler performance. M.Sc. Thesis, Fac. Agric, Tanta Univ., Tanta, Egypt.

Estevez, I. (2007). Density allowance for broilers, where to set the limits. Poultry Science. 86:1265-1272.

Feddes, J.J., Emmanuel, E.J., Zuidhof, M. J. (2002). Broiler performance, body weight variance, feed and water intake and carcass quality at different stocking densities. Poultry Science. 81, 774-779.

Fetuga B. L. A. (1984). Technique in feed formulation. Paper presented at the feed mill management training workshop, Department of Agricultural Economics, University of Ibadan.

Jafarnejad, S., \& Sadegh, M. (2011). The effect of different levels of dietary protein, energy and using fat on the performance of broiler chicks at the end of the third week. Asian Journal of Poultry Science, Pp.6.

Kamran, Z., Mirza, M. A., \& Mahmood, S. (2004). Effect of decreasing dietary protein levels with optimum amino acids profile on the performance of broilers. In Pakistan Veterinary Journal, 24(4), 165-168.

Kamran, Z. M., Sarwar, M., Nisa, M. A., Nadeem, S., Admad, S., Mushtaq, T., Ahmad, T. \& Shahzad, M. A. (2008b). Effect of lowering dietary protein with constant energy to protein ratio on growth, body composition and nutrient utilization of broiler chicks. Asian-Australasian Journal of Animal Sciences, 21(11), 1629-1634.

Kamran, Z., Sarwar, M., Nisa, M., Nadeem, M. A., Mahmood, S., Babar, M. E., \& Ahmed, S. (2008a). Effect of low-protein diets having constant energy-to-protein ratio on performance and carcass characteristics of broiler chicken from one to thirty-five days of age. Poultry Science. 87:468-474.

Leeson, S. L., Coston, L., \& Summers, J. D. (1996). Broiler response to energy or energy and protein dilution in the finisher diet. Poultry Science, 75, 522-528.

Nahashon, S. N., Adefope, N., Amehyenu, A., \& Wright, D. (2005). Effect of dietary metabolizable energy and crude protein concentration on growth performance and carcass characteristics of French Guinea broilers. Poultry Science. 84, 337-344.

Nawaz, H., Mushtaq, T., \& Yaqoob, M. (2006). Effect of varying levels of energy and protein on live performance and carcass characteristics of broiler chicks. The Journal of Poultry Science, 43(4), 388-393.

Nguyen, T. V., Chaiyapoom, B., \& Somchai, C. (2010). Effect of dietary protein and energy on growth performance and carcass characteristics of betong chickens (Gallus domesticus) during Growing Period. International Journal of Poultry Science, 9(5), 468-472.

Nogueira, W. C. L., Velasquez, P. A. T., Furlan, R. L., Macari, M. (2013). Effect of dietary energy and stocking density on the performance and sensible heat loss of broilers reared under Tropical Winter Conditions. Brazilian Journal of Poultry Science, Vol.15 (1), 53-58.

NRC (1994). Nutrient Requirements of Poultry, $9^{\text {th }}$ ed. National Academic Press. Washington D.C. USA.

Puron, D., Santamaria, R., Segura, J. C., \& Alamilla, J. L. (1995). Broiler performance at different stocking densities. The Journal of Applied Poultry Research, 4(1), 55-60.

Ravindran, V., Thomas, D. V., Thomas, D. G., \& Morel, P. C. (2006). Performance and welfare of broiler as affected by stocking density and Zinc bacteracin supplementation. Animal Science Journal, 77, 110-116.
Rosa, P. S., Faria Filho, D. E., Dahlke, F., Vieira, B. S., Macari, M., \& Furlan, R. L. (2007). Effect of energy intake on performance and carcass composition of broiler chickens from two different genetic groups. Brazilian Journal of Poultry Science, 9(2), 117-122.

SAS, (2008). User's Guide: Statistics. Version 9.2, SAS Institute Inc., Cary, NC. USA.

Shahin, K. A., \& Abd Elazeem, F. (2005). Effects of breed, sex and diet and their interactions on carcass composition and tissue weight distribution of broiler chickens. Archiv fur Tierzucht, 48(6), 612- 626.

Simsek, U. G., Cerci, I. H., Dalkilic, B., Yilmaz, O., \& Ciftci, M. (2009). Impact of stocking density and feeding regimen on broilers: Chicken meat composition, fatty acids, and serum cholesterol levels. The Journal of Applied Poultry Research, 18(3), 514-520.

Skinner, J. T., Waldroup, A. L., \& Waldroup, P. W. (1992). Effects of dietary nutrient density on performance and carcass quality of broilers 42 to 49 days of age. The Journal of Applied Poultry Research, 1(4), 367-372.

Škrbić, Z., Pavlovski, Z., Lukić, M., Perić, L., \& Milošević, N. (2009). The effect of stocking density on certain broiler welfare parameters. Biotechnology in Animal Husbandry, 25(1-2), 11-21.

Summers, J. D., Spratt, D., Atkinson, J. L. (1992). Broiler weight gain and carcass composition when fed diets varying in amino acid balance, dietary energy and protein level. Poultry science, 71(2), 263-273.

Thaxton J. P., Dozier, W. A., Branton, S. L., Morgan, G. W., Miles D. M., Roush, W. B., Lott, B. D., Vizzier-Thaxton, Y. (2006). Stocking density and physiological adaptive responses of broilers. Poultry science, 85, 819-824.

Thomas, D. G, Ravindran, V., Thomas, D. V., Camden, B. J., Cottan, Y. H., Morei, P. C. H., Cook, C. J. (2004). Influence of stocking density on the performance, carcass characteristics and selected welfare indicators of broiler chicken. New Zealand Veterinary Journal, 52, 76-81.

Tong, H. B., Lu, J., Zou, J. M., Wang, Q., Shi, S. R. (2012). Effects of stocking density on growth performance, carcass yield, and immune status of a local chicken breed. Poultry science, 91:667-673.

Waldroup, P. W., Mitchell, R. J., Payne, J. R., \& Johnson, Z. B. (1976).Characterization of the response of broiler chickens to diets varying in nutrient density content. Poultry Science, 55, 130-145.

Yadgari, L., Kinreich, R., Druyan, S., Cahaner, A. (2006). The effect of stocking density in hot condition on growth, meat yield and meat quality of featherless and feathered broilers, XII European Conference, Verona, Italy. World Poultry Science Journal, 62, 603.

Yakubu, A., Ayoade, J. A., \& Dahiru, Y. M. (2010). Effects of genotype and population density on growth performance, carcass characteristics, and cost-benefits of broiler chickens in north central Nigeria. Tropical animal health and production, 42(4), 719-727.

Zaman, Q. U., Mushtaq, T., Nawaz, H., Mirza, M. A., Mahmood, S., Ahmad, T., Babar, M. E., \& Mushtaq, M. M. H. (2008). Effect of varying dietary energy and protein on broiler performance in hot climate. Animal Feed Science and Technology, 146(3), 302-312. 